Article

\title{
Life Cycle Cost Analysis Comparison of Hot Mix Asphalt and Reclaimed Asphalt Pavement: A Case Study
}

\author{
Waqas Rafiq ${ }^{1,2}$, Muhammad Ali Musarat ${ }^{1, *}$, Muhammad Altaf ${ }^{1}\left({ }^{1}\right.$, Madzlan Napiah $^{1}$, Muslich Hartadi Sutanto ${ }^{1}$,

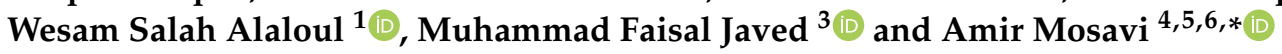 \\ 1 Department of Civil and Environmental Engineering, Universiti Teknologi PETRONAS, Bandar Seri Iskandar, \\ Tronoh 32610, Malaysia; waqas_18000277@utp.edu.my (W.R.); muhammad_20000250@utp.edu.my (M.A.); \\ madzlan_napiah@utp.edu.my (M.N.); muslich.sutanto@utp.edu.my (M.H.S.); \\ wesam.alaloul@utp.edu.my (W.S.A.) \\ 2 Department of Civil Engineering, COMSATS University Islamabad, Wah Cantt 47040, Pakistan \\ 3 Department of Civil Engineering, COMSATS University Islamabad Abbottabad Campus, \\ Khyber Pakhtunkhwa 22060, Pakistan; arbabfaisal@cuiatd.edu.pk \\ 4 Faculty of Civil Engineering, Technische Universität Dresden, 01069 Dresden, Germany \\ 5 Institute of Structural Mechanics, Bauhaus Universität-Weimar, 99423 Weimar, Germany \\ 6 John von Neumann Faculty of Informatics, Obuda University, 1034 Budapest, Hungary \\ * Correspondence: muhammad_19000316@utp.edu.my (M.A.M.); amir.mosavi@mailbox.tu-dresden.de (A.M.)
}

Citation: Rafiq, W.; Musarat, M.A.; Altaf, M.; Napiah, M.; Sutanto, M.H.; Alaloul, W.S.; Javed, M.F.; Mosavi, A. Life Cycle Cost Analysis Comparison of Hot Mix Asphalt and Reclaimed Asphalt Pavement: A Case Study. Sustainability 2021, 13, 4411. https:// doi.org/10.3390/su13084411

Academic Editor: Rui Micaelo

Received: 15 March 2021

Accepted: 12 April 2021

Published: 15 April 2021

Publisher's Note: MDPI stays neutral with regard to jurisdictional claims in published maps and institutional affiliations.

Copyright: (c) 2021 by the authors. Licensee MDPI, Basel, Switzerland. This article is an open access article distributed under the terms and conditions of the Creative Commons Attribution (CC BY) license (https:/ / creativecommons.org/licenses/by/ $4.0 /)$.

\begin{abstract}
In the construction and maintenance of asphalt pavement, reclaimed asphalt pavement (RAP) is being widely used as a cheaper alternative to the conventional hot mix asphalt (HMA). HMA incorporated with a high RAP content (e.g., 40\%), which is the most commonly used, may have prominent adverse effects on life cycle, performance properties, and related costs. Thus, before utilizing RAP, it is essential to investigate whether it is still economical to use under the local climate by taking into consideration the life cycle performance. Therefore, for this paper, a case study was conducted using 20\% RAP, assessed in terms of materials related to cost analysis. The results of the analysis showed that, from the total life cycle costing measurement, a total of $14 \%$ cost reduction was reported using RAP as compared to conventional materials. Moreover, the two materials (conventional HMA and RAP) are manufactured in different types of manufacturing plants. Thus, in analyzing the cost difference between the two chosen manufacturing plants for virgin materials and RAP, a total of $57 \%$ cost reduction was observed for a RAP manufacturing plant. Besides this, no cost difference was observed in the rest of the phases, such as manpower, materials transportation, and construction activities, as the same procedures and types of machinery are used. Furthermore, assessing the carbon dioxide impact and cost, the transportation and machinery emissions were considered, while the plant's operation emission was omitted due to the unavailability of the data.
\end{abstract}

Keywords: life cycle cost analysis (LCCA); recycling; $\mathrm{CO}_{2}$; reclaimed asphalt pavement; life cycle performance; mobility; sustainable development; infrastructures; sustainable materials; asphalt

\section{Introduction}

Asphaltic concrete is extensively used for pavement construction all around the world. Road networks and transportation infrastructures play a critical role in the development of countries. The global population growth and the urge for economic development had significantly contributed in the expansion of the road networks in particular asphalt roads and highways. In the United States, Canada, Europe, Mexico, and Asia, more than 3.68, 0.41, $4.68,0.17$ and 3.8 million $\mathrm{km}$ of roads are paved with asphaltic concrete [1,2]. Therefore, new roads' construction, their maintenance, restoration, rehabilitation and reconstruction, and aged pavement preservation, require an enormous volume of materials and the consumption of unreproducible energy sources, which have huge cost demands that impact the economy. Alongside these processes of new road construction and maintenance, toxic 
gaseous emissions enter the environment, and huge landfills are regenerated, which are risky and life-threatening factors for the environment ecosystem. Categorically, infrastructure projects have negative impacts, which create significant concern. To overcome the negative impacts of infrastructure projects and optimize the cost, various strategies are adopted by policymakers. Likewise, utilizing recycled materials along with virgin materials are the best alternatives to optimize the cost and impact of an infrastructure project [3-8].

Asphalt pavements containing recycled asphalt material have major impacts in terms of low cost as well as environmental life cycle benefits in comparison to conventional hot mix asphalt pavements; the use of reclaimed asphalt (RA) is typical because of its economic benefits in production and the environmental effects of the transportation of the raw materials [9-13]. Using higher RA contents in pavements results in lower life cycle costs. The RA material is a milled material obtained as a waste byproduct via the use of any rehabilitation technique, and it can be used by any recycling alternative in hot mix asphalt (HMA) [14]. Qiao, et al. [15] carried out a life cycle cost analysis (LCCA) for Interstate 95 (I-95) in New Hampshire (NH), USA, to evaluate and compare the cash flow life cycle of road structures that were under construction. During this study, a further two parameters (overlay responsive maintenance and its corresponding efficiency) were also considered. The study found that the use of $40 \%$ recycled asphalt in a mix reduced agency costs by up to $18 \%$ in the predicted 2020-2040 climate perspective, and to reduce capital costs, national highway agencies should consider this practice in the context of the predicted future climate. Considering LCCA, utilizing recycled asphalt is typically economic and has eco-friendly benefits [16]. The cycle of cash flow is not limited to the two phases that include the production of material and the materials' transportation, but it includes all life recycling and rehabilitation phases during the construction of pavements.

Lee, et al. [17] studied the subsurface layers (base and subbase) in terms of their economic benefits by utilizing the recycled asphalt material in these layers, which was evaluated quantitively by conducting a cost cycle analysis on the pavement by comparing the conventional material or virgin material and other recycled asphalt materials in the construction of a highway in Wisconsin. The analysis of results indicated that the utilization of recycled materials in the subsurface layers (base and subbase) would cause a considerable reduction in global warming $(20 \%)$, the consumption of energy $(16 \%)$, water consumption $(11 \%)$, hazardous waste generation $(11 \%)$ and life cycle costs $(21 \%)$, and using recycled materials also extended the serviceable life of the pavement. These savings will be reduced even further if the cost of landfill avoidance is taken into account for the reclaimed material used in the asphalt pavement [17].

Santos, et al. [18] conducted LCCA considering the agency and user costs, which included delays due to the work zone and crash costs. During LCCA, the international roughness index (IRI) was used as an indicator to measure the performance of the pavement, which also helps in the estimation of pavement service life. It was concluded that using reclaimed asphalt pavement (RAP) can be helpful in the reduction of life cycle costs by approximately $20 \%$ as compared to conventional pavements. Similarly, Santos, et al. [18] conducted a comprehensive cost analysis study wherein the economic advantages and disadvantages of RAP and conventional hot mix asphalt pavements were compared. The LCCA includes all the phases, starting from materials procurement, through to design production, construction, maintenance, restoration, transportation, costs in the work zone, and ending with the recycling phase. IRI was used in the study, which is frequently measured via many cost analysis studies, whereby it was concluded that utilizing RAP impacts the reduction of agency and user costs depending on the rutting and cracking performance of the pavement [19]. Moreover, Coleri, et al. [20] performed a simulation based on a mechanistic empirical approach to the life cycle performance and cost analysis of reclaimed and control asphalt pavement for a wide-ranging life cycle performance evaluation, intended to investigate ensuing pavement preservation interventions and related life cycle cost components [20]. 
The LCCA considered the costs related to raw materials, machinery, manpower, traffic management, and costs involved in lane closure. In RAP, the LCCA life cycle is an important performance parameter because of its impact on the functionality, riding surface quality, agency costs significantly affected by maintenance costs, and costs on the user's end, which include the consumption of fuel in terms of efficiency [21-25]. For the further improvement of the calculation of the life cycle performance of recycled asphalt usage, a dynamic mechanical performance test must be performed because of the variations, and the RA's performance is evaluated based on laboratory tests. There is normally a consensus that RAP improves the rutting resistance of asphalt roads, and a negative reduction in thermal cracking resistance occurs because aged material increases the brittleness of the mixtures [26-31]. These scenarios recommend the use of rejuvenating agents in a mix design utilizing a RAP percentage of more than $25 \%$. Restoring the aged binder's physical and chemical properties are the main objectives of any rejuvenating agent $[32,33]$. Performance indicators such as rutting, cracking and roughness are used for the multiple life cycle analyses, which assess the LCCA and life cycle impact of the pavement. In designing conventional mixes and LCCAs, a stationary climate is usually assumed. In infrastructure sensitive to climate, the life cycle performance and costs can have different impacts when the climate pattern changes in the future. For example, in cold climates, for asphalt pavements, rutting may not be a damaging concern, but deterioration because of thermally induced cracking can be an issue. On the other hand, for hot climatic regions, rutting performance can be a central issue, and thermal cracking may be critical. Therefore, this should be kept in mind when considering local climate changes and responses generated by the materials when estimating the performance based on life cycle analysis and pavement cost [24,34-37].

According to the European Asphalt Pavement Association (EAPA), 2015, the total asphalt production in the United States, Japan, and 30 European countries from 2008 to 2015 was 5485.3 million tons. Globally, the production of asphalt is higher than the above stated figures. These data show that the production of asphalt material around the world is huge, and so analyzing the detrimental impact of manufacturing this amount of asphalt on the environment is important for the preservation of the natural environment. The financial benefit is considered the most important standard when selecting any option among different economic options. In the context of nonconformance, inadequate construction practices, and the huge funds required for the maintenance and continuous expansion of road projects, road authorities around the world are investigating innovative methods and practices for minimizing the expenses of pavement projects. Life cycle cost, economic and environmental analyses have been gaining attention in the last few years [24,38].

Two approaches are generally classified as cost analysis: the first is to reduce the asphalt pavement price, and the second is to reduce the cost related to materials [39-41]. The various designed and studied mixture proportions did not take into account the mix operation because of the practicability of making these mixes with conventional equipment. This study's aim was to inspect an approach based on the reduction of the cost of materials; however, another approach was also investigated for comparison. International articles were used to compare the unit costs of different asphalt mixtures. A results analysis showed that the price of production for green asphalt pavement is considerably lower than that of conventional HMA. The lowest cost was for the mix incorporating 100\% RAP, then waste engine oil (WEO), followed by crumb rubber (CRM); the per unit price of asphalt for this mixture reduced from USD 66.4 to USD 17. Similarly, the 100\% RAP-CRM-WEO displayed a $74 \%$ reduction in cost, and the cost of materials used was also reduced.

Virgin asphalt pavement contributes to a higher range of materials consumption, which increases the construction cost and causes distress among stakeholders, whereas recycled asphalt is one of the more viable and highly recommended options for the maintenance of high traffic-loaded gravel roads, in addition to the usage of recycled material, which has been discussed already [41]. Thus, the following study was conducted to weigh up the costs and benefits of utilizing RAP. Therefore, this study aims to perform a cost 
analysis evaluation of flexible pavements constructed with $20 \%$ RAP, in comparison to virgin asphalt pavement, so as to provide objective guidance to road agencies aimed at evaluating the benefits and risks of using recycled asphalt materials in their pavements. Additionally, the potential impacts of utilizing RAP in HMA on materials, manpower, and transport and plant operation costs was assessed. Moreover, this study identifies and quantifies various factors that should be included in a cost-benefit analysis of the different applications of RAP. Besides this, a case study has been performed that considers the utilization of RAP and conventional materials in a highway project, which provides examples and descriptions of how to perform the cost-benefit analysis.

\section{Methodology}

The processes of extraction, production, transportation, and finally road construction are included in the life cycle analysis of road pavements. The remaining steps are skipped due to the difficulties of collecting such appropriate data for the chosen materials. The methodology adopted for the case study is shown in Figure 1.

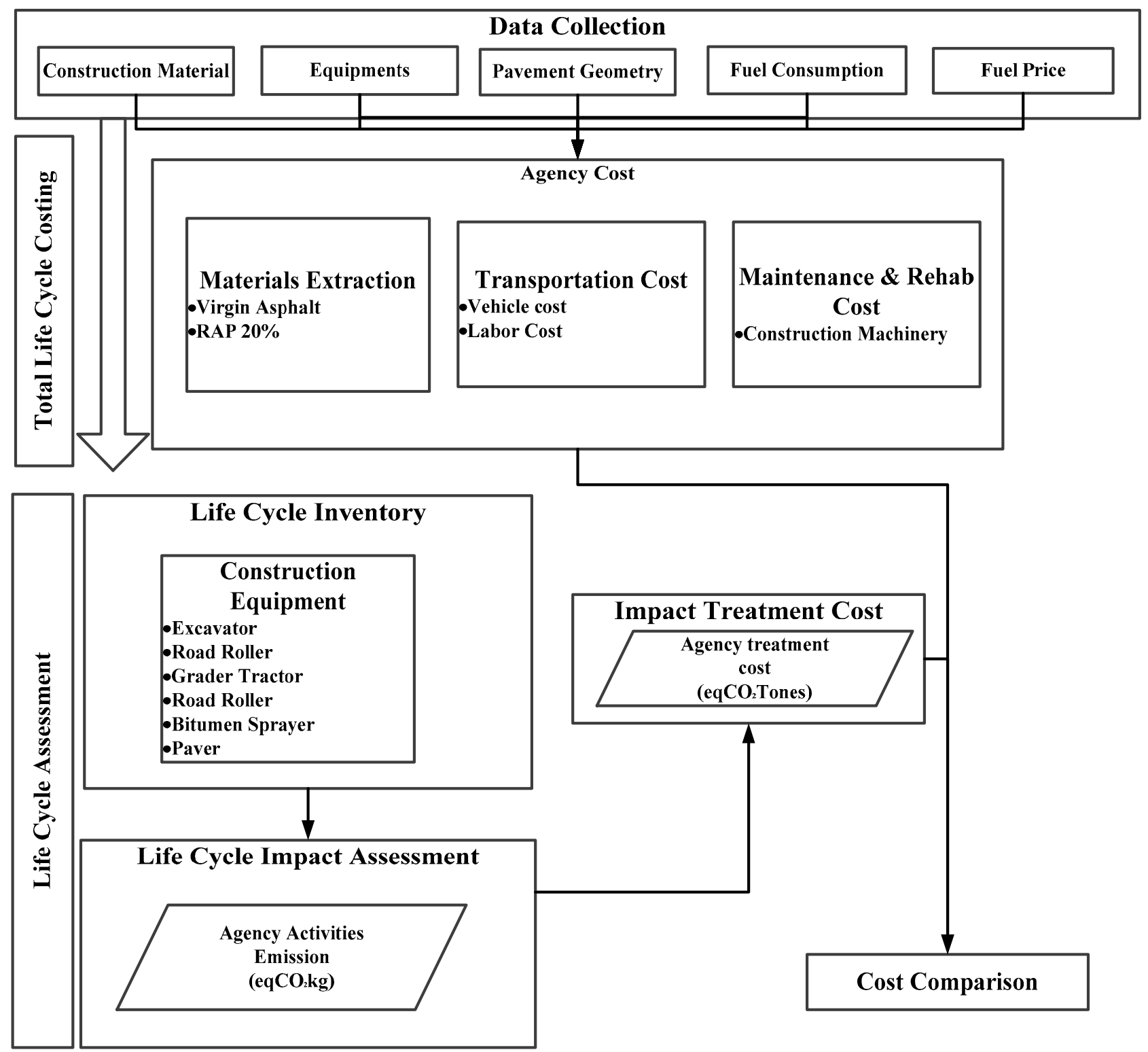

Figure 1. Research flowchart. 
For the current study, the Lahore-Islamabad Motorway (M-2), a six-lane (three lanes in each direction) expressway connecting two major cities in Pakistan was considered. The motorway was completed and opened to traffic in 1997. The length of the LahoreIslamabad (M-2) is $354 \mathrm{~km}$ [41]. The originally designed life of M-2 was 10 years, while the pavement structure with a good design exceeded the design life by more than 15 years, and the serviceability level was still acceptable, with very minor maintenance and rehabilitation (M\&R) work done. Currently, the motorway requires major modernization through the application of potentially major restoration and rehabilitation techniques. A complete structural and functional evaluation of all existing lanes must be considered to determine the cost-effectiveness of pavement, involving pavement preservation treatment, rehabilitation, and life-cycle cost analyses (LCCA) to extend the service life for another 10 years or more. The functional conditions and structural stresses along the motorway must be thoroughly analyzed in order to select the proper and most cost-effective pavement rehabilitation and preservation options for improving its structural capacity and serviceability. To fulfil the objective of this study, the research team utilized cost information from the National Highway Authority (NHA). For life cycle evaluation, certain tools exist, such as Real cost 2.5, SimaPro and OneClickLCA [6], which were reviewed. After a detailed assessment of the tools, an Excel tool sheet was developed in which LCA and LCCA were integrated, with the incorporation of carbon costs to analyze different alternative materials. Moreover, a cost comparison was conducted between virgin and RAP materials for the rehabilitation of the highways in order to enhance the project's performance for the next 10 years.

\section{Results and Discussion}

\subsection{Life Cycle Cost Analysis}

The cost analysis functional unit is the total capital cost expressed in million US dollars, considering the road per mile $(1.6 \mathrm{~km})$ extending the pavement service life of 10 years. The cost life cycle cost analysis mainly focuses on the parts of the cost involved in pavement construction that have a direct impact payable by stakeholders, i.e., highway agencies, construction firms, etc. The phases which are involved are life cycle cash flows and costs in the whole process of asphalt pavement, as well as the total production cost, which includes raw materials involved in the asphalt mix, recycled asphalt, and different types of graded aggregates needed for the construction of a 1 mile unit length of road. The transportation cost involves fuel consumption for the transportation of asphalt mixtures, recycled asphalt and aggregates to the construction site, the transfer of equipment to the construction site and the transport of material to the recycling plant. The construction cost includes the machinery, which includes the different types of rollers and pavers for the laying of asphalt material. The maintenance cost includes the overlay during the maintenance of the road and the equipment involved in the maintenance period.

\subsubsection{Materials Cost}

The purpose of the assessment is to evaluate a cost-effective material alternative with a minimal environmental impact. In the study, two main alternative materials are considered for the rehabilitation of the highway project, and these are virgin bitumen and RAP. The first alternative materials considered consist of virgin bitumen (4.3\%) and the necessary aggregates, as shown in Table 1. 
Table 1. Cost breakdown of virgin materials.

\begin{tabular}{cccc}
\hline S. No & Material & Unit & Cost (USD) \\
\hline 1 & Bitumen $(4.3 \%)$ & Ton & 27,904 \\
2 & Crush 10-20 mm (38\%) & Ton & 4630 \\
3 & Crush 05-10 mm (20\% & Ton & 2325 \\
4 & Crush 00-05 mm (42\%) & Ton & 2112 \\
5 & Light Diesel Oil (LDO) & Ltr & 5216 \\
\hline & Total cost & 42,187 \\
\hline
\end{tabular}

The second alternative consists of $20 \%$ RAP and $80 \%$ virgin asphalt, as shown in Table 2. The aggregate for both the virgin alternative and the RAP is the same. Moreover, the RAP material purchase cost was zero, as the same materials extracted from the old pavement were utilized for remanufacturing. However, the costs of energy, i.e., the fuel utilized for the extraction of RAP by machines and dumps trucks, are considered along with materials transportation and rehabilitation activities.

Table 2. Cost breakdown of recycled materials.

\begin{tabular}{cccc}
\hline S. No & Material & Unit & Cost (USD) \\
\hline 1 & Bitumen $(4.3 \%)$ & & \\
& Virgin $(80 \%)$ & Ton & 22,323 \\
& RAP $(20 \%)$ & Ton & - \\
2 & Crush 10-20 mm (38\%) & Ton & 4630 \\
3 & Crush 05-10 mm (20\% & Ton & 2325 \\
4 & Crush 00-05 mm (42\%) & Ton & 2112 \\
5 & LDO & Ltr & 5216 \\
\hline
\end{tabular}

\subsubsection{Production Cost}

Material production is an important phase wherein the materials are generated, or old materials are recycled, in order to substitute the virgin materials depleted during their consumption. In the current study, two types of plants are utilized for the manufacturing of virgin asphalt and recycled asphalt. In the manufacturing of the virgin alternative, two asphalt plants for the manufacturing of virgin materials were used, whereas one doublebarrel asphalt plant was used for the recycled materials [42]. The cost breakdown of the plants' operation and activities is shown in Table 3, wherein the costs of plant operation are the same for both materials.

\subsubsection{Materials Transportation and Construction Activities}

In this phase, the costs of material transportation and construction, as well as machinery costs, are considered as shown in Table 4 [43]. The transportation phase includes the transport of asphalt mixture, RAP, gravel, and sand to the construction site, along with the transportation of end-of-life materials from the site to the recycling plant $[44,45]$. 
Table 3. Cost breakdown of plant activities and operation.

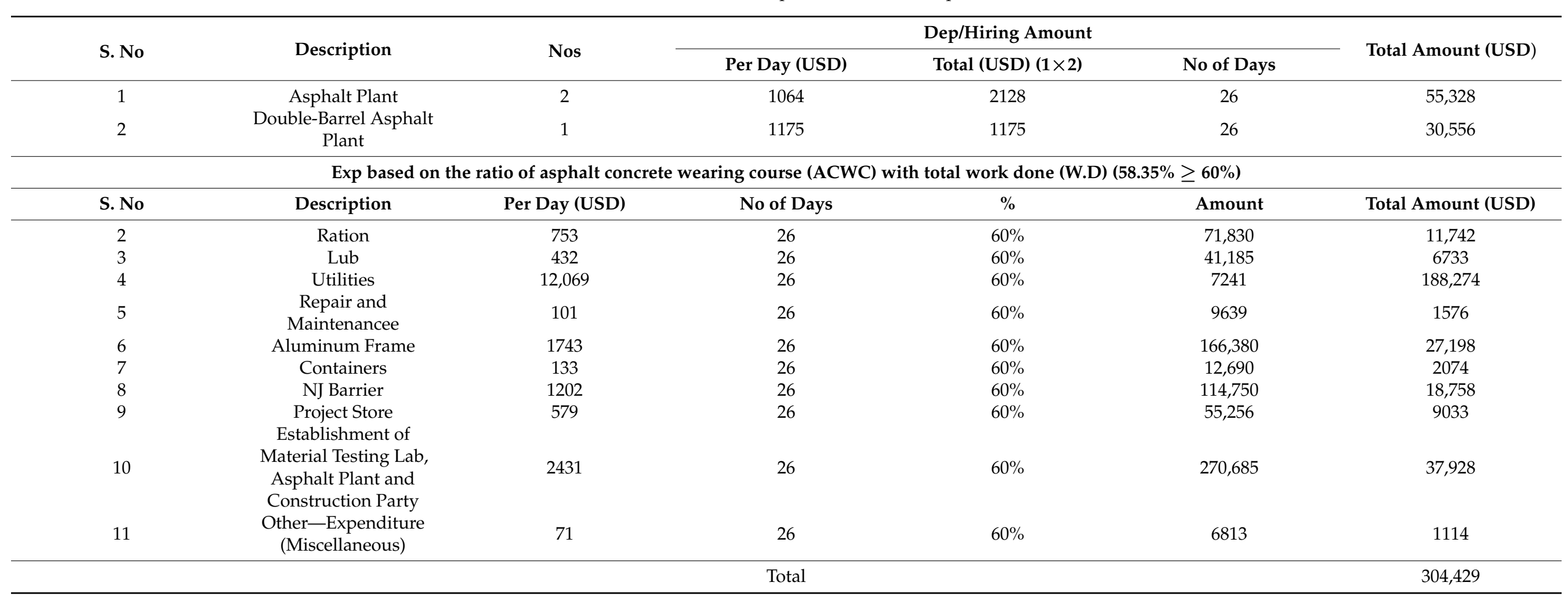


Table 4. Cost breakdown of material transportation and construction activities.

\begin{tabular}{|c|c|c|c|c|c|c|c|c|}
\hline \multirow[b]{2}{*}{ S. No } & \multirow[b]{2}{*}{ Make and Type } & \multirow[b]{2}{*}{ Nos } & \multicolumn{2}{|c|}{ Dep/Hiring Amount } & \multirow{2}{*}{$\begin{array}{l}\text { Petroleum Oil Lubricants } \\
\text { (POL) } \\
\text { Consumed per Day (11 h) }\end{array}$} & \multirow[b]{2}{*}{$\begin{array}{l}\text { POL Rate } \\
\text { (USD) }\end{array}$} & \multirow{2}{*}{$\begin{array}{l}\text { Total POL } \\
\text { Amount } \\
\text { (USD) }\end{array}$} & \multirow{2}{*}{$\begin{array}{c}\text { Total Amount } \\
\text { (Dep/Hiring + POL) } \\
\text { (USD) }\end{array}$} \\
\hline & & & $\begin{array}{c}\text { per Month (26 days) } \\
\text { USD }\end{array}$ & $\begin{array}{l}\text { Total } \\
\text { (USD) }\end{array}$ & & & & \\
\hline 1 & $\begin{array}{c}\text { Pneumatic Tire Rollers } \\
\text { (PTR) }\end{array}$ & 6 & 1163 & 6979 & 55 & 0.69 & 228 & 7207 \\
\hline 2 & Tandem Roller & 3 & 1415 & 4244 & 66 & 0.69 & 137 & 4381 \\
\hline 3 & Paver & 2 & 4715 & 9431 & 220 & 0.69 & 304 & 9735 \\
\hline 4 & Loader & 2 & 1572 & 3144 & 209 & 0.69 & 288 & 3432 \\
\hline 5 & Fuel Bowzer & 1 & 1100 & 1100 & 15 & 0.69 & 10 & 1111 \\
\hline 6 & Generator (400 KVA) & 2 & 2672 & 5344 & 550 & 0.69 & 759 & 6103 \\
\hline 7 & $\begin{array}{c}\text { Material Transfer } \\
\text { Vehicles (MTV) }\end{array}$ & 2 & 8865 & 17,730 & 88 & 0.69 & 121 & 17,852 \\
\hline 8 & Dumper & 32 & 2201 & 70,418 & 180 & 0.69 & 3974 & 74,393 \\
\hline 9 & Air Compressor & 4 & 1006 & 4024 & 154 & 0.69 & 425 & 4449 \\
\hline 10 & Tractor (With Boomer) & 5 & 346 & 1729 & 55 & 0.69 & 190 & 1919 \\
\hline 11 & Water Bowzer & 2 & 817 & 1635 & 80 & 0.69 & 110 & 1745 \\
\hline 12 & S/Cabin & 5 & 409 & 2043 & 30 & 0.69 & 104 & 2147 \\
\hline 13 & $\mathrm{D} / \mathrm{C}$ & 5 & 472 & 2358 & 40 & 0.69 & 138 & 2496 \\
\hline
\end{tabular}




\subsubsection{Pavement Maintenance and Rehabilitation}

RAP increases the resistance of asphalt pavements to rutting, but it reduces the resistance to thermal cracking, because old material makes the mixtures more brittle. As a result, water infiltration through cracks during seasonal changes can accelerate pavement degradation, resulting in major issues such as moisture damage, base failure, and potholes. Thus, to overcome this problem, the maintenance cost for deterioration of RAP was calculated for the timely treatment of pavement quality throughout its service life. The rehabilitation of the highways was considered after 10 years; thus, routine maintenance after 3 years was scheduled as shown in Table 5, in order to increase the pavement life and to enhance the performance of the pavement. Moreover, the virgin asphalt materials in pavements face less damage, and thus the maintenance cost for virgin materials was assessed after 6 years. As such, the overall $M \& R$ cost for RAP rises compared to the virgin materials.

Table 5. Maintenance and rehabilitation cost breakdown.

\begin{tabular}{cccc}
\hline \multirow{2}{*}{ Component Activity } & Year & \multicolumn{2}{c}{ Cost (USD) } \\
\cline { 3 - 4 } & & RAP & Virgin \\
\hline M\&R\# 1 & 3 & 2000 & - \\
M\&R \# 2 & 6 & 2000 & 3000 \\
M\&R \# 3 & 9 & 2000 & - \\
\hline \multicolumn{2}{c}{ Total M\&R Cost } & 6000 & 3000 \\
\hline
\end{tabular}

\subsubsection{Manpower Cost}

The manpower cost is the cost related to the operators of the plant, the contractors, the machinery operators and the supervisor [46-48], as shown in Table 6.

Table 6. Manpower cost breakdown.

\begin{tabular}{ccc}
\hline S. No & Description & Amount (USD) \\
\hline 1 & Manpower Civil & 877 \\
2 & Manpower army (60\% of & 1571 \\
\hline
\end{tabular}

\subsubsection{Environmental Impact and Costing}

The purpose of this phase was to assess the environmental impacts, such as $\mathrm{CO}_{2}$ emissions, and measure the environmental cost that should be utilized or imposed by the legislation in order to counter the harmful impact caused by the pavement project. In assessing the total impact, a life cycle inventory is generated, as shown in Table 7 . The main phases impacting the environment are found in the material production, such as the emissions from the plants, whereas in road construction and maintenance, the machinery is responsible for gaseous emissions [37,38,41,49,50]. The plant utilizes fossil fuels in manufacturing, and the machinery utilizes the same. The petroleum oil lubricants (POL) data were collected from the plant operator and NHA department supervising the project, and were used to evaluate the $\mathrm{CO}_{2}$ emission. The total POL measurements were then converted into $\mathrm{CO}_{2}$ emissions, whereby $1 \mathrm{~L}$ of petrol is equal to 2.19 Equivalent $(\mathrm{Eq}) \mathrm{CO}_{2}$ $\mathrm{Kg}$. Moreover, to integrate the environmental cost, the $\mathrm{Eq} \mathrm{CO}_{2} \mathrm{~kg}$ is converted into tons, where a carbon price was assigned, such as USD 35 per ton of emission. 
Table 7. Life cycle inventory and impact assessment.

\begin{tabular}{|c|c|c|c|c|c|c|c|c|}
\hline S. No & $\begin{array}{l}\text { Main } \\
\text { Tasks }\end{array}$ & $\begin{array}{l}\text { Daily } \\
\text { Hours }\end{array}$ & $\begin{array}{c}\text { Number of } \\
\text { Days }\end{array}$ & $\begin{array}{l}\text { POL Consumed } \\
\text { per Hour }(\mathrm{L})\end{array}$ & $\begin{array}{c}\text { Total POL } \\
\text { Consumed (L) }\end{array}$ & $\mathrm{Eq} \mathrm{CO}_{2} \mathrm{~kg}$ & Tons & $\begin{array}{l}\mathrm{CO}_{2} \text { Cost } \\
\text { (USD) }\end{array}$ \\
\hline 1 & $\begin{array}{c}\text { Pneumatic } \\
\text { Tire Rollers } \\
\text { (PTR) }\end{array}$ & 11 & 26 & 5 & 1430 & 3132 & 3.13 & 109.61 \\
\hline 2 & $\begin{array}{l}\text { Tandem } \\
\text { Roller }\end{array}$ & 11 & 26 & 6 & 1716 & 3758 & 3.76 & 131.53 \\
\hline 3 & Paver & 11 & 26 & 20 & 5720 & 12,527 & 12.53 & 438.44 \\
\hline 5 & Loader & 11 & 26 & 19 & 5434 & 11,900 & 11.90 & 416.52 \\
\hline 6 & $\begin{array}{l}\text { Fuel } \\
\text { Bowzer }\end{array}$ & - & 26 & 15 & 390 & 854 & 0.85 & 29.89 \\
\hline 7 & $\begin{array}{l}\text { Generator } \\
\text { (400 KVA) }\end{array}$ & 11 & 26 & 40 & 11,440 & 25,054 & 25.05 & 876.88 \\
\hline 9 & $\begin{array}{c}\text { Material } \\
\text { Transfer } \\
\text { Vehicles } \\
(\mathrm{MTV})\end{array}$ & 11 & 26 & 9 & 2574 & 5637 & 5.64 & 197.30 \\
\hline 10 & Dumper & - & 26 & 180 & 4680 & 10,249 & 10.25 & 358.72 \\
\hline 11 & $\begin{array}{l}\text { Air Com- } \\
\text { pressor }\end{array}$ & 11 & 26 & 14 & 4004 & 8769 & 8.77 & 306.91 \\
\hline 13 & $\begin{array}{l}\text { Tractor } \\
\text { (With } \\
\text { Boomer) }\end{array}$ & 11 & 26 & 5 & 1430 & 3132 & 3.13 & 109.61 \\
\hline 14 & $\begin{array}{l}\text { Water } \\
\text { Bowzer }\end{array}$ & - & 26 & 80 & 2080 & 4555 & 4.56 & 159.43 \\
\hline 15 & S/Cabin & - & 26 & 30 & 780 & 1708 & 1.71 & 59.79 \\
\hline 16 & $\mathrm{D} / \mathrm{C}$ & - & 26 & 40 & 1040 & 2278 & 2.28 & 79.72 \\
\hline \multicolumn{5}{|c|}{ Total } & 42,718 & 93,552 & 94 & 3274 \\
\hline
\end{tabular}

\subsubsection{Total Life Cycle Costing}

At the end of the study, a detailed comparison was conducted among the various phases of the two chosen alternative materials, as shown in Figure 2. From the conducted total life cycle costing measurement, a 14\% total cost reduction was reported using RAP as compared to conventional materials. The reason for the reduction in the RAP materials cost was that the materials from the existing pavement were utilized, hence the materials purchasing cost was zero. RAP materials still involve some costs related to energy used during RAP extraction. Moreover, the two alternative materials are manufactured via different techniques in different types of manufacturing plants. Thus, when analyzing the cost difference between the two chosen manufacturing plants for virgin materials and RAP, a 57\% total cost reduction can observed for a RAP manufacturing plant. The RAP materials extracted from existing pavements are usually already graded and refined, and thus less energy is utilized for their further material processing. Besides this, a $66 \%$ increase was noticed in the costs of the RAP related to R\&M activities as compared to virgin materials. The increase in the $M \& R$ occurred due to the presence of old materials, which make the pavement brittle and cause earlier degradation. Thus, to overcome the degradation in the RAP, more scheduled M\&R activities are required than for the virgin materials. Moreover, no cost difference was observed in the rest of the phases, such as manpower, material transportation, and construction activities, as the same procedures and types of machinery are used. Furthermore, in assessing the $\mathrm{CO}_{2}$ impacts and costs, transportation and machinery emissions were considered, whereas the plant operation emission is omitted due to the unavailability of the data. 


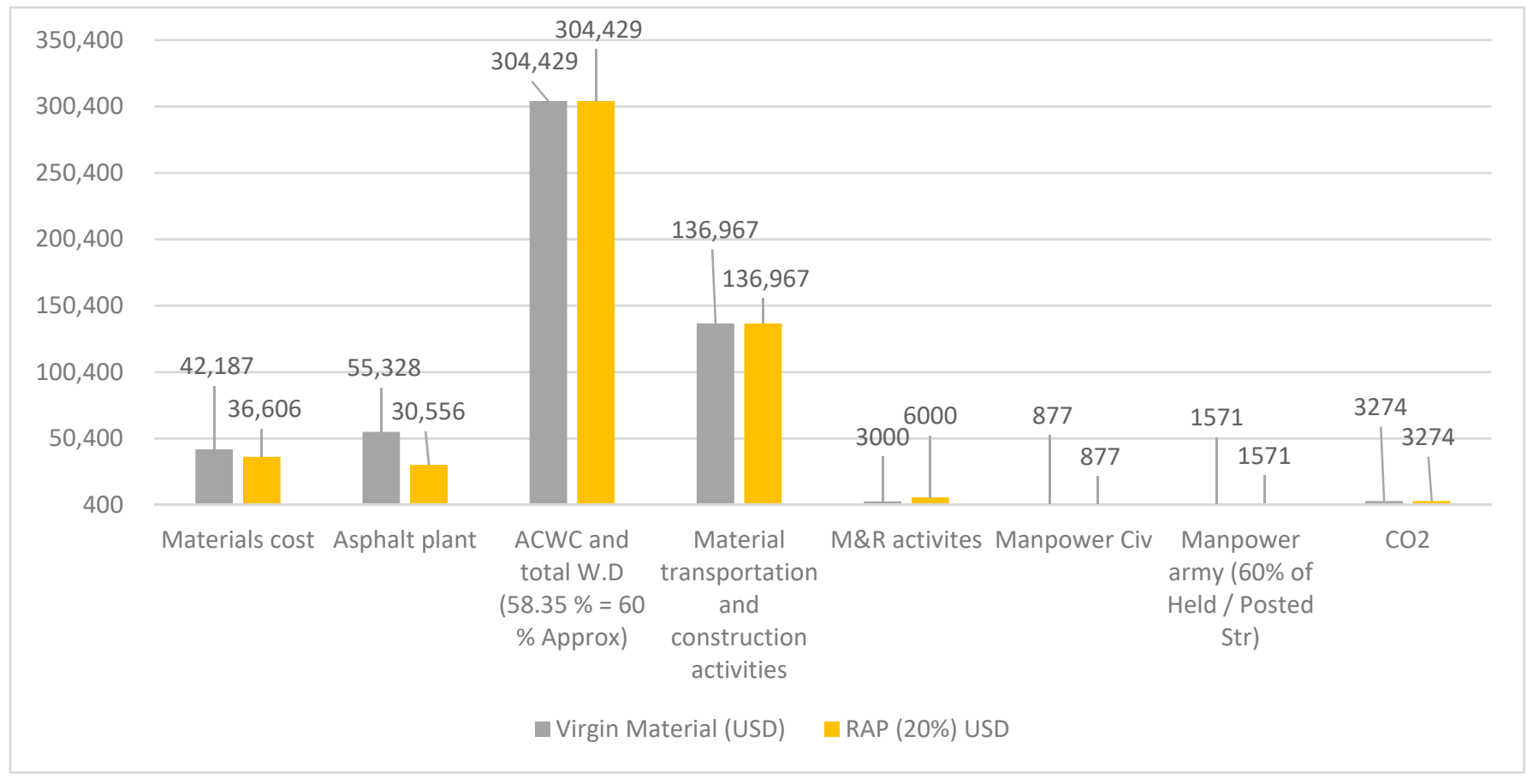

Figure 2. Total life cycle costing of virgin and RAP.

\section{Conclusions}

Given the available funds within road agencies and the high costs involved in maintenance, to further increase the road infrastructure, the optimization of the economic aspect is one of the most important parts of pavement maintenance. Therefore, considering this aspect, this study investigated the life cycle costs of two asphalt concrete options on the Lahore-Islamabad motorway (M-2), a six-lane (three lanes in each direction) expressway connecting two major cities in Pakistan. The unit of analysis is considered in million US dollar, and it assessed a 1 mile stretch of roadway over the span of 10 years of pavement life. The two mix alternatives are control/virgin HMA and HMA containing 20\% reclaimed asphalt. A life cycle cost analysis was conducted by taking into consideration the processes of extraction, production, transportation, and finally road construction. The following conclusions can be drawn:

- From the conducted total life cycle costing measurement, a $14 \%$ total cost reduction was reported using $20 \% \mathrm{RAP}$, which can be a more economical practice than using $100 \%$ new HMA;

- When analyzing the cost difference between the two chosen manufacturing plants for virgin materials and RAP, a 57\% total cost reduction can be observed in the RAP manufacturing plant;

- Besides this, no cost difference was observed in the rest of the phases, such as manpower, materials transportation, and construction activities, as the same procedures and types of machinery are used;

- The maintenance and rehabilitation costs of the RAP-containing pavements increased as compared to conventional asphalt pavement roads. Three maintenance and rehabilitation programs were used for RAP-containing roads. Therefore, this increased the maintenance cost by $50 \%$ as compared to the HMA road, but still the capital cost for both alternatives, RAP-containing road is more economical;

- For the assessment of the $\mathrm{CO}_{2}$ impact and cost, the transportation and machinery emissions were considered, and the total Petroleum Oil Lubricant (POL) measured were then converted into $\mathrm{CO}_{2}$ emissions, whereby $1 \mathrm{~L}$ of petrol is equal to $2.19 \mathrm{Eq} \mathrm{CO}_{2}$ 
$\mathrm{Kg}$. Moreover, to integrate the environmental cost, the $\mathrm{Eq} \mathrm{CO}_{2} \mathrm{~kg}$ is converted into tons, and then a carbon price was assigned, such as USD 35 per ton of emission.

Author Contributions: All authors contributed equally to this research. All authors have read and agreed to the published version of the manuscript.

Funding: This research received no external funding.

Institutional Review Board Statement: Not applicable.

Informed Consent Statement: Not applicable.

Data Availability Statement: Data is available within this manuscript.

Acknowledgments: The authors would like to thank Universiti Teknologi PETRONAS (UTP) for the support provided for this research. Open Access Funding by the Publication Fund of the TU Dresden. Amir Mosavi would like to thank Alexander von Humboldt Foundation.

Conflicts of Interest: The authors declare no conflict of interest.

\section{References}

1. Copeland, A. Reclaimed Asphalt Pavement in Asphalt Mixtures: State of the Practice; Federal Highway Administration; Office of Research: Washington, DC, USA, 2011.

2. Shi, X.; Mukhopadhyay, A.; Zollinger, D.; Grasley, Z. Economic input-output life cycle assessment of concrete pavement containing recycled concrete aggregate. J. Clean. Prod. 2019, 225, 414-425. [CrossRef]

3. Li, J.; Xiao, F.; Zhang, L.; Amirkhanian, S.N. Life cycle assessment and life cycle cost analysis of recycled solid waste materials in highway pavement: A review. J. Clean. Prod. 2019, 233, 1182-1206. [CrossRef]

4. Anthonissen, J. Bituminous Pavements in Flanders: Quantifying the Effect of Rap on the Environmental Impact; University of Antwerp: Antwerp, Belgium, 2017.

5. Dossche, C.; Boel, V.; de Corte, W. Use of Life Cycle Assessments in the Construction Sector: Critical Review. Procedia Eng. 2017, 171, 302-311. [CrossRef]

6. Riekstins, A.; Haritonovs, V.; Straupe, V. Life Cycle Cost Analysis and Life Cycle Assessment for Road Pavement Materials and Reconstruction Technologies. Balt. J. Road Bridg. Eng. 2020, 15, 118-135. [CrossRef]

7. Musarat, M.; Alaloul, W.; Liew, M.; Maqsoom, A.; Qureshi, A. The Effect of Inflation Rate on $\mathrm{CO}_{2}$ Emission: A Framework for Malaysian Construction Industry. Sustainability 2021, 13, 1562. [CrossRef]

8. Bukhari, H.; Alaloul, W.S.; Musarat, M.A.; Akram, S.; Tabassum, I.; Altaf, M. Materializing Low-Cost Energy-Efficient Residential Utility through Effective Space Design and Masonry Technique-A Practical Approach. Civ. Eng. Arch. 2021, 9, 357-374. [CrossRef]

9. Giani, M.I.; Dotelli, G.; Brandini, N.; Zampori, L. Comparative life cycle assessment of asphalt pavements using reclaimed asphalt, warm mix technology and cold in-place recycling. Resour. Conserv. Recycl. 2015, 104, 224-238. [CrossRef]

10. Aurangzeb, Q.; Al-Qadi, I.L.; Ozer, H.; Yang, R. Hybrid life cycle assessment for asphalt mixtures with high RAP content. Resour. Conserv. Recycl. 2014, 83, 77-86. [CrossRef]

11. Yang, R.; Ozer, H.; Kang, S.; Al-Qadi, I.L. Environmental impacts of producing asphalt mixtures with varying degrees of recycled asphalt materials. Resour. Conserv. Recycl. 2015, 104, 141-151. [CrossRef]

12. Santos, J.; Bryce, J.; Flintsch, G.; Ferreira, A.; Diefenderfer, B. A life cycle assessment of in-place recycling and conventional pavement construction and maintenance practices. Struct. Infrastruct. Eng. 2014, 11, 1199-1217. [CrossRef]

13. Del Ponte, K.; Natarajan, B.M.; Ahlman, A.P.; Baker, A.; Elliott, E.; Edil, T.B. Life-Cycle Benefits of Recycled Material in Highway Construction. Transp. Res. Rec. J. Transp. Res. Board 2017, 2628, 1-11. [CrossRef]

14. Arimilli, S.; Jain, P.K.; Nagabhushana, M.N. Optimization of recycled asphalt pavement in cold emulsified mixtures by mechanistic characterization. J. Mater. Civ. Eng. 2016, 28, 04015132. [CrossRef]

15. Aurangzeb, Q.; Al-Qadi, I.L. Asphalt pavements with high reclaimed asphalt pavement content: Economic and environmental perspectives. Transp. Res. Rec. 2014, 2456, 161-169. [CrossRef]

16. Qiao, Y.; Dave, E.; Parry, T.; Valle, O.; Mi, L.; Ni, G.; Yuan, Z.; Zhu, Y. Life Cycle Costs Analysis of Reclaimed Asphalt Pavement (RAP) Under Future Climate. Sustainability 2019, 11, 5414. [CrossRef]

17. Walls, J.; Smith, M.R. Life-Cycle Cost Analysis in Pavement Design: Interim Technical Bulletin; Federal Highway Administration: Washington, DC, USA, 1998.

18. Lee, J.C.; Edil, T.B.; Tinjum, J.M.; Benson, C.H. Quantitative Assessment of Environmental and Economic Benefits of Recycled Materials in Highway Construction. Transp. Res. Rec. J. Transp. Res. Board 2010, 2158, 138-142. [CrossRef]

19. Santos, J.; Bryce, J.; Flintsch, G.; Ferreira, A. A comprehensive life cycle costs analysis of in-place recycling and conventional pavement construction and maintenance practices. Int. J. Pavement Eng. 2015, 18, 727-743. [CrossRef] 
20. Wang, Y. The effects of using reclaimed asphalt pavements (RAP) on the long-term performance of asphalt concrete overlays. Constr. Build. Mater. 2016, 120, 335-348. [CrossRef]

21. Coleri, E.; Zhang, Y.; Wruck, B.M. Mechanistic-Empirical Simulations and Life-Cycle Cost Analysis to Determine the Cost and Performance Effectiveness of Asphalt Mixtures Containing Recycled Materials. Transp. Res. Rec. J. Transp. Res. Board 2018, 2672, 143-154. [CrossRef]

22. Chatti, K.; Zaabar, I. Estimating the effects of pavement condition on vehicle operating costs. Transp. Res. Board 2012, 720, 63-76.

23. Trupia, L.; Parry, T.; Neves, L.C.; Presti, D.L. Rolling resistance contribution to a road pavement life cycle carbon footprint analysis. Int. J. Life Cycle Assess. 2016, 22, 972-985. [CrossRef]

24. Wang, T.; Lee, I.-S.; Kendall, A.; Harvey, J.T.; Lee, E.-B.; Kim, C. Life cycle energy consumption and GHG emission from pavement rehabilitation with different rolling resistance. J. Clean. Prod. 2012, 33, 86-96. [CrossRef]

25. Inyim, P.; Pereyra, J.; Bienvenu, M.; Mostafavi, A. Environmental assessment of pavement infrastructure: A systematic review. J. Environ. Manag. 2016, 176, 128-138. [CrossRef]

26. Alaloul, W.S.; Altaf, M.; Musarat, M.A.; Faisal Javed, M.; Mosavi, A. Life Cycle Assessment and Life Cycle Cost Analysis in Infrastructure Projects: A Systematic Review. Preprints 2021, 2021030316, 1-37. [CrossRef]

27. Al-Qadi, I.L.; Elseifi, M.; Carpenter, S.H. Reclaimed Asphalt Pavement-A Literature Review; Callaway Industrial Services: Mooresville, NC, USA, 2007.

28. Shu, X.; Huang, B.; Vukosavljevic, D. Laboratory evaluation of fatigue characteristics of recycled asphalt mixture. Constr. Build. Mater. 2008, 22, 1323-1330. [CrossRef]

29. Silva, H.M.; Oliveira, J.R.; Jesus, C.M. Are totally recycled hot mix asphalts a sustainable alternative for road paving? Resour. Conserv. Recycl. 2012, 60, 38-48. [CrossRef]

30. Qiao, Y.; Dawson, A.R.; Parry, T.; Flintsch, G.W. Evaluating the effects of climate change on road maintenance intervention strategies and Life-Cycle Costs. Transp. Res. Part D Transp. Environ. 2015, 41, 492-503. [CrossRef]

31. Rafiq, W.; Bin Napiah, M.; Sutanto, M.H.; Alaloul, W.S.; Zabri, Z.N.B.; Khan, M.I.; Musarat, M.A. Investigation on Hamburg Wheel-Tracking Device Stripping Performance Properties of Recycled Hot-Mix Asphalt Mixtures. Materials 2020, $13,4704$. [CrossRef]

32. Rafiq, W.; Bin-Napiah, M.; Sutanto, M.H.; Alaloul, W.S.; Khan, M.I.; Al-Sabaeei, A. Performance Evaluation for Rutting and Moisture damage of Hot Asphalt Mixtures using High Percentage of Recycled Asphalt Pavement Material. In Proceedings of the IOP Conference Series: Earth and Environmental Science, Johor, Malaysia, 19-20 December 2019; IOP Publishing: Bristol, UK, 2020; p. 498.

33. Ābele, A.; Merijs-Meri, R.; Bērzina, R.; Zicāns, J.; Haritonovs, V.; Ivanova, T. Effect of bio-oil on rheological and calorimetric properties of RTFOT aged bituminous compositions. Int. J. Pavement Res. Technol. 2021, 14, 537-542. [CrossRef]

34. Rafiq, W.; Humair, M.; Bin Napiah, M.; Sutanto, M.H.; Musarat, M.A.; Memon, A.M. Performance Evaluation of Rutting and Moisture Damage containing Warm Mix Asphalt Mixtures with Recycled Asphalt pavement. In Proceedings of the 2020 Second International Sustainability and Resilience Conference: Technology and Innovation in Building Designs (51154), Sakheer, Bahrain, 11-12 November 2020; IEEE: Piscataway, NJ, USA, 2020; pp. 1-7.

35. Underwood, B.S.; Guido, Z.; Gudipudi, P.; Feinberg, Y. Increased costs to US pavement infrastructure from future temperature rise. Nat. Clim. Chang. 2017, 7, 704-707. [CrossRef]

36. Chinowsky, P.S.; Schweikert, A.E.; Strzepek, N.; Strzepek, K. Road Infrastructure and Climate Change in Vietnam. Sustainability 2015, 7, 5452-5470. [CrossRef]

37. Miliutenko, S.; Björklund, A.; Carlsson, A. Opportunities for environmentally improved asphalt recycling: The example of Sweden. J. Clean. Prod. 2013, 43, 156-165. [CrossRef]

38. Yu, B.; Wang, S.; Gu, X. Estimation and uncertainty analysis of energy consumption and $\mathrm{CO}_{2}$ emission of asphalt pavement maintenance. J. Clean. Prod. 2018, 189, 326-333. [CrossRef]

39. Golestani, B.; Nam, B.H.; Ercan, T.; Tatari, O.; Brandon, T.L.; Valentine, R.J. Life-Cycle Carbon, Energy, and Cost Analysis of Utilizing Municipal Solid Waste Bottom Ash and Recycled Asphalt Shingle in Hot-Mix Asphalt. Geotech. Front. 2017, 333-344. [CrossRef]

40. Jahanbakhsh, H.; Karimi, M.M.; Naseri, H.; Nejad, F.M. Sustainable asphalt concrete containing high reclaimed asphalt pavements and recycling agents: Performance assessment, cost analysis, and environmental impact. J. Clean. Prod. 2020, $244,118837$. [CrossRef]

41. Zheng, X.; Easa, S.M.; Yang, Z.; Ji, T.; Jiang, Z. Life-cycle sustainability assessment of pavement maintenance alternatives: Methodology and case study. J. Clean. Prod. 2019, 213, 659-672. [CrossRef]

42. Work, R.M. Government of Pakistan. 2005. Available online: http://nha.gov.pk/ (accessed on 10 February 2021).

43. Cao, R.; Leng, Z.; Yu, H.; Hsu, S.-C. Comparative life cycle assessment of warm mix technologies in asphalt rubber pavements with uncertainty analysis. Resour. Conserv. Recycl. 2019, 147, 137-144. [CrossRef]

44. NHA, Composite Schedule of Rate (CSR), N.H. Department, Editor: Pakistan. Available online: http:/ / nha.gov.pk/en/compositeschedule-of-rate-csr (accessed on 10 February 2021).

45. Vidal, R.; Moliner, E.; Martínez, G.; Rubio, M.C. Life cycle assessment of hot mix asphalt and zeolite-based warm mix asphalt with reclaimed asphalt pavement. Resour. Conserv. Recycl. 2013, 74, 101-114. [CrossRef] 
46. Chen, X.; Wang, H. Life cycle assessment of asphalt pavement recycling for greenhouse gas emission with temporal aspect. J. Clean. Prod. 2018, 187, 148-157. [CrossRef]

47. Robinson, G.R., Jr.; Menzie, W.D.; Hyun, H. Recycling of construction debris as aggregate in the Mid-Atlantic Region, USA. Resour. Conserv. Recycl. 2004, 42, 275-294. [CrossRef]

48. Edwards, D.J.; Holt, G.D. Construction plant and equipment management research: Thematic review. J. Eng. Des. Technol. 2009, 7, 186-206. [CrossRef]

49. Coelho, A.; de Brito, J. Economic analysis of conventional versus selective demolition-A case study. Resour. Conserv. Recycl. 2011, 55, 382-392. [CrossRef]

50. Huang, Y.; Hakim, B.; Zammataro, S. Measuring the carbon footprint of road construction using CHANGER. Int. J. Pavement Eng. 2013, 14, 590-600. [CrossRef] 